\title{
CORPORATE SOCIAL RESPONSIBILITY AS A TOOL TO ENSURE EMPLOYEE WELLBEING
}

In Happiness And Contemporary Society : Conference Proceedings Volume (Lviv, March, 20-21, 2021). Lviv: SPOLOM, 2021. P. 114-117. https://doi.org/10.31108/7.2021.25

ISBN 978-966-919-697-2 


\section{GIGAURI Iza}

PhD in Business Administration, Associate Professor, School of Business, Computing and Social Sciences, Saint Andrews Georgian University (Tbilisi, Georgia)

\section{CORPORATE SOCIAL RESPONSIBILITY AS A TOOL TO ENSURE EMPLOYEE WELLBEING}

The recent economic and social transformations due to the new coronavirus pandemic have enforced organizations to change business processes. Moreover, the lockdown regulations aiming at preventing the spread of the virus have induced accelerated digitalization. Businesses and employees have to adapt quickly and overcome difficulties with innovative strategies that can be derived from creative, motivated, satisfied, and happy employees. Corporate Social Responsibility (CSR) not only creates a better brand image for a company and contributes to organizational values and culture, but also positively affects employees' job satisfaction. The paper discusses the implication of CSR practice on employee satisfaction and examines the influence of CSR on employee wellbeing during the crisis. The presented paper is based on previous research aiming at analyzing the implications of the pandemic on CSR in Georgian companies.

KEYWORDS: Employee, Wellbeing, Pandemic, CSR, Georgia.

\section{INTRODUCTION}

The COVID-19 pandemic as an international humanitarian crisis (Kaul et al., 2020) has caused rapid changes in economic, and social dimensions around the globe and forced organizations to alter business processes.

The current pandemic crisis is metaphorically viewed as a "Black Swan" event because of its unique characteristics, unpredictability, and extraordinary effects on society, and economics (Taleb, 2007; Winston, 2020). Since there are no previous experience and models to tackle such a large-scale crisis, innovative approaches need to be followed, which can be derived from creative, motivated, satisfied, and happy employees.

Moreover, the lockdown regulations aiming at preventing the spread of the virus have induced accelerated digitalization. Businesses and employees have to adapt quickly to the new reality to survive and succeed. In this regard, corporate social responsibility (CSR) plays an important role in a company's effort to support employees, communities, and society in order to stay in the market. Besides, CSR can help companies to navigate through turbulent times as it is based on values and mission, which are enduring.

CSR is a corporate behavior and management philosophy that considers the economic, social, and environmental impacts of a company. Companies with CSR try to minimize the negative footprints as well as improve societal wellbeing through business practices. Nowadays, society expects from the business to go beyond legislation framework and act ethically within all their operations. Consequently, modern 
companies are judged by customers, investors, and the public in the light of their CSR activities.

CSR helps in building up a better image for a company and contributes to a supportive organizational culture, which positively affects employees' job satisfaction.

The paper is devoted to examining the influence of corporate social responsibility on employee wellbeing and discusses the implication of CSR practice on employee satisfaction. It is based on previous research meant to investigate the crisis effect on CSR, which also investigated CSR efforts of Georgian companies to contribute to the employees' and community's health and safety during the pandemic.

The rest of the paper is organized as follows. First, the current literature is discussed. Then, CSR activities toward employee wellbeing in Georgia are analyzed followed by the conclusions. Finally, suggestions of future research directions are outlined.

\section{THEORETICAL BACKGROUND}

The pandemic crisis has enforced companies to digitalize their business processes and move online. Employees working remotely need more support from their organizations, which can be provided easily under the framework of CSR as it ensures work-life balance as well as the health and safety of employees (Gigauri, 2021). In this respect, sustainable human resource management helps to solve problems (Aust et al., 2020), and hence, to tackle the pandemic crisis.

In order to motivate employees and ensure their happiness, human resource managers should offer more than basic hygiene factors such as appropriate pay, safe and secure job, but also companies need to give workers a sense of responsibility, and recognition (Riggio, 2015). People need to know that they are working for the public good, not solely for the profit maximization of founders. When organizational values are in line with employees' values, they are satisfied and happy with their job. The CSR concept enables companies to create and maintain values with the engagement of the workforce.

The research confirms that CSR has a positive influence and even can be a source of employee satisfaction (Kim et al., 2020; Bauman \& Skitka, 2012).

The recent research confirmed the positive correlation between CSR activities and employees' happiness, as CSR influences the organizational culture that can enhance employee happiness (Espasandín-Bustelo et al., 2020). Moreover, CSR practices impact employee satisfaction that in turn leads to employee commitment to organizational objectives (Barakat et al., 2016).

Consequently, managers should enable flexibility, innovation, autonomy, communication, and supporting culture (Espasandín-Bustelo et al., 2020), which are achieved through CSR.

As the workforce have a key role to play in the accomplishment of organizational objectives, CSR programs need to support employees' physical and emotional wellbeing and to improve the working environment (Sigala, 2020). Thus, employees will be motivated and work with commitment.

Furthermore, recent studies have discovered that employees are satisfied with how their companies dealt with the pandemic through CSR initiatives (Mao et al., 2020). 
Thus, CSR impacts employee wellbeing, whereas satisfied employees contribute to companies' goals.

\section{RESEARCH RESULTS}

The research conducted in Georgia revealed that CSR projects were addressed to employee and community wellbeing (Gigauri, 2021).

During the pandemic, the main concern of CSR programs was the health and safety of employees (Gigauri, 2021). Moreover, companies with established CSR have not dismissed employees, nor send them to unpaid leave. On the contrary, they increased salaries to some extent and even hired new employees as planned (Gigauri, 2021).

Additionally, CSR helped companies to communicate with employees and to maintain organizational value and culture (Gigauri, 2021).

According to the research results, top management supported CSR projects, and encouraged CSR initiatives, as CSR practice is a strategic focus area of their companies (Gigauri, 2021).

The research findings indicate that CSR creates values and helps companies to make ethical decisions during the crisis. The concept highlights the importance of employees, as valuable assets for the business.

Furthermore, the health and safety of the workforce, employees' physical and mental welfare are the most vital for business continuity during the pandemic, and CSR is a tool to ensure the achievement of these goals.

\section{CONCLUSIONS}

The literature review emphasizes the positive correlation between CSR and employee satisfaction. CSR programs enable employee engagement, improve the brand image and reputation of a company, and support organizational culture and values, which ultimately leads to employee happiness.

The research has shown, that employee protection was the main concern of CSR during the lockdown in Georgian companies. The top management has supported CSR projects and encouraged CSR initiatives in order to produce results.

The sustainable, profitable business contributes to the economy, keeps the unemployment rate lower, and promotes community development with CSR in place. CSR helps companies to protect the reputation and improve brand image during the crisis, which then positively influences employee satisfaction.

Thus, organizations should develop CSR with a strategic emphasis on employee wellbeing to survive and succeed in the long-term.

Future studies should focus on the role of CSR in employee wellbeing, and examine factors of employee happiness that are influenced by CSR in different types and sizes of organizations.

\section{REFERENCES}

1. Aust, I., Matthews, B., \& Muller-Camen, M. (2020). Common Good HRM: A paradigm shift in Sustainable HRM? Human Resource Management Review, 30(3), 100705 https://doi.org/10.1016/j.hrmr.2019.100705 
2. Barakat, S. R., Isabella, G., Boaventura, J. M. G., \& Mazzon, J. A. (2016). The influence of corporate social responsibility on employee satisfaction. Management Decision, 54(9), 2325-2339. https://doi.org/10.1108/md-05-2016-0308

3. Bauman, C. W., \& Skitka, L. J. (2012). Corporate social responsibility as a source of employee satisfaction. Research in Organizational Behavior, 32, 63-86. https://doi.org/10.1016/j.riob.2012.11.002

4. Espasandín-Bustelo, F., Ganaza-Vargas, J., \& Diaz-Carrion, R. (2020). Employee happiness and corporate social responsibility: the role of organizational culture. Employee Relations: The International Journal. https://doi.org/10.1108/er07-2020-0343

5. Gigauri, I. (2021). Corporate Social Responsibility and COVID-19 Pandemic Crisis. International Journal of Sustainable Entrepreneurship and Corporate Social Responsibility, 6(1), 30-47. https://doi.org/10.4018/ijsecsr.2021010103

6. Kaul, V., Shah, V. H., \& El-Serag , H. (2020). Leadership During Crisis: Lessons and Applications from the COVID-19 Pandemic. Gastroenterology, https://doi.org/10.1053/ j.gastro.2020.04.076.

7. Kim, H. L., Rou, Y., Topcuoglu, E., \& Kim, Y. (2020). Why hotel employees care about Corporate Social Responsibility (CSR): Using Need Satisfaction Theory. International Journal of Hospitality Management, 87, 1025050. https://doi.org/10.1016/j.ijhm.2020.102505

8. Mao, Y., He, J., Morrison, A. M., \& Coca-Stefania, J. A. (2020). Effects of tourism CSR on employee psychological capital in the COVID-19 crisis: from the perspective of conservation of resources theory. Current Issues in Tourism, https://doi.org/10.1080/13683500.2020.1770706

9. Riggio, R. (2015). Introduction to Industrial and Organizational Psychology. Routledge.

10. Sigala, M. (2020). Tourism and COVID-19: impacts and implications for advancing and resetting industry and research. Journal of Business Research, 117, 312-321. https://doi.org/10.1016/j.jbusres. 2020.06.015

11. Taleb, N. N. (2007). The Black Swan. Random House.

12. Winston, A., (2020). Is the COVID-19 Outbreak a Black Swan or the New Normal? MIT Sloan Management Review. March. https://sloanreview.mit.edu/article/is-thecovid-19-outbreak-a-black-swan-or-the-new-normal/ 